\title{
Disparity in ozone trends under COVID-19 lockdown in a closely located coastal and hillocky metropolis of India
}

\author{
Nikhil Korhale ${ }^{1,2} \cdot$ Vrinda Anand $^{1,2} \cdot$ Gufran Beig $^{1}$ \\ Received: 8 August 2020 / Accepted: 15 October 2020 / Published online: 31 October 2020 \\ (C) Springer Nature B.V. 2020
}

\begin{abstract}
The outbreak of COVID-19, a global health challenge faced by countries worldwide, led to a lockdown in India, thereby bringing down the emissions of various air pollutants. Here, we discuss the behaviour of surface ozone $\left(\mathrm{O}_{3}\right)$ concentrations and its precursors, oxides of nitrogen $\left(\mathrm{NO}_{\mathrm{x}}\right)$, carbon monoxide $(\mathrm{CO})$, and volatile organic compounds (VOC) at two Indian megacities namely Mumbai and Pune, closely located yet vastly differing in meteorology due to their locations. Although levels of CO, $\mathrm{NO}_{2}$, and VOC declined sharply after the lockdown in both cities, with $\mathrm{NO}_{2}$ showing the highest reduction, ozone concentration in Pune remained unaffected, whereas Mumbai exhibited a mixed trend, touching even a maximum in between the lockdown. On a diurnal scale, the magnitude of $\mathrm{O}_{3}$ levels during the lockdown period is higher at almost all hours in Mumbai, and in Pune, it is almost identical except during night hours when it is marginally higher in the lockdown period as compared to the normal period. On a whole, the pollution levels were brought down significantly which can be used as a benchmark in the future for the implementation of policies related to air quality management and emission control in Indian megacities by the policymakers. These results also can pave a way for the scientific community for local air quality modelling.
\end{abstract}

Keywords Ozone $\cdot$ COVID-19 $\cdot$ Air pollution $\cdot$ Megacities $\cdot$ Emission $\cdot$ CO $\cdot$ VOC

\section{Introduction}

The spread of the COVID-19 pandemic is a global public health crisis; the disease has affected more than 100 countries worldwide (WHO, 2020). The explosion of the COVID-19 cases around the world has made it a global pandemic and brings about devastating consequences (Wang et al. 2020). The COVID-19 has been affirmed to have human to human transmission, and thus to contain its spread, nations worldwide have been going into lockdowns. India registered its first confirmed case of COVID-19 on 30th January 2020, thereafter which from March 4th onwards, a jump in the number of cases was observed. To contain the large-scale spread of COVID-19, the Indian government following suit of many other countries that went into a lockdown declared a nationwide lockdown from 25th March 2020. During this period, all

Gufran Beig

beig@tropmet.res.in

1 Indian Institute of Tropical Meteorology, Ministry of Earth Sciences (MoES), Pune, India

2 Savitribai Phule Pune University, Pune, India private and public gatherings were suspended; road, rail, and air transportations were banned; and all activities were put on hold. The lockdown led to a decrease in the emissions of various air pollutants, and thus it became a major research topic to study the levels of various air pollutants (Kerimray et al. 2020). It was observed that in China, due to the lockdown, there was a decrease in economic activities, and traffic restrictions led to a decrease in their energy consumption which further prevented the atmosphere from being polluted (Wang et al. 2020). Reduction in $\mathrm{NO}_{2}$ has been reported in many countries which went into lockdown (Bao and Zhang 2020; Shereen et al. 2020; Tobías et al. 2020).

India too has recorded a reduction in various pollutants like $\mathrm{PM}_{2.5}, \mathrm{PM}_{10}, \mathrm{CO}$, and $\mathrm{NO}_{2}$ (Sharma et al. 2020a; Sharma et al. 2020b; Singh and Chauhan 2020) Along with these pollutants, another pollutant affecting the atmosphere is tropospheric $\mathrm{O}_{3}$. It is a toxic pollutant that plays an important role in the regional climate and causes adverse effects on human health and vegetation (Lin et al. 2018, Zhang et al. 2019). Since it is a secondary pollutant, formed by the photochemical reactions between nitrogen oxides and volatile organic compounds (VOCs), it is necessary to study the precursor pollutants as well. The $\mathrm{O}_{3}$ formation increases with increasing concentrations of VOCs, while rising levels of $\mathrm{NO}_{\mathrm{x}}$ lead to an 
increase/decrease of $\mathrm{O}_{3}$ depending on the prevailing ratio between VOCs and $\mathrm{NO}_{\mathrm{x}}$ (Pancholi et al. 2018). $\mathrm{O}_{3}$ production is dependent on the state of $\mathrm{NO}_{\mathrm{x}}$, as $\mathrm{NO}_{2}$ and $\mathrm{NO}$ increase the production and dissociation of $\mathrm{O}_{3}$, respectively (Hagenbjörk et al. 2017). Therefore, a change in the $\mathrm{NO} / \mathrm{NO}_{2}$ ratio results in an increase or decrease of the $\mathrm{O}_{3}$ concentration (Fischer et al. 2006; Melkonyan and Kuttler 2012). $\mathrm{O}_{3}$ is greatly influenced by prevailing meteorological conditions, viz. temperature, wind, relative humidity, and solar flux (Lu et al. 2019; Resmi et al. 2020). Many observations have shown that $\mathrm{O}_{3}$ concentration increases with an increase in temperature and solar flux (Pudasainee et al., 2006; Khiem et al. 2010; Han et al. 2011). It has been shown in many studies that surface $\mathrm{O}_{3}$ is considered the most damaging air pollutant in terms of adverse health effects on human health, vegetation, crops, and materials in many places, and it may become worse in the future (Mills et al., 2011; H. Liu et al. 2018; Sicard et al. 2017).

India has been seeing a rise in the number of COVID-19 cases ever since the lockdown has been operational. In India, the western state of Maharashtra has the highest number of COVID-19 cases. There are two megacities in Maharashtra which bear the maximum number of COVID-19 cases in this state, i.e. Mumbai and Pune. Mumbai a coastal city, is the country's financial powerhouse, the nation's industrial heartland, and the second most populous metropolitan area in India, with a population of 18 million. Pune is situated $100 \mathrm{~km}$ inland from the west coast and is in close proximity to Mumbai city, but it has completely different geography as it is not a coastal city. It is at an altitude of $598 \mathrm{~m}$ above sea level. It is a city with many educational institutes and IT industries and has a population of 5 million. In this study, we investigate ozone and its precursor pollutant concentrations in two closely located cities and how it varies during the lockdown period which is from 17th March 2020 to 14th April 2020. This study helps in understanding the pollutant levels in reduced emission scenario and how it can pave a way forward for the policymakers while building mitigation strategies for controlling the air pollution levels in India.

\section{Data and methodology}

The study location includes two megacities that are in proximity to each other but have different geographical and weather conditions, as shown in Fig. 1. Mumbai $\left(19.0760^{\circ} \mathrm{N}\right.$, $72.8777^{\circ} \mathrm{E}$ ) is a coastal city on the western part of India and thus has coastal meteorology. Pune $\left(18.5204^{\circ} \mathrm{N}, 73.8567^{\circ} \mathrm{E}\right)$ is located at a higher altitude and is on the leeward side of the Sahyadri range of mountains. The System of Air Quality and Weather Forecasting and Research (SAFAR) network which has been established in Pune and Mumbai consists of 8 to 10 air quality monitoring stations (AQMS) covering the whole city which continuously measures various pollutant levels and weather parameters. This network covers different microenvironments of the city including industrial, residential, background, urban, and semi-urban locations. Locations are chosen in such a way that the average of these may be considered representative of the city, as per WMO guidelines (Beig et al. 2015). The averaged value of all these stations for a particular city has been used in this work. The US-EPA approved online analysers are used to monitor $\mathrm{O}_{3}, \mathrm{CO}, \mathrm{NO}_{\mathrm{x}}$ $\left(\mathrm{NO}+\mathrm{NO}_{2}\right)$, and VOC concentrations continuously, every $5 \mathrm{~min}$ (Anand et al. 2020). The ground-level ozone was measured by the ozone analyser O342 (Environment SA, France) through the UV light absorption method, in which the amount of UV light absorbed is proportional to the amount of ozone present in the air, with a measurement range of $0-10 \mathrm{ppm}$ and accuracy of $< \pm 2 \%$. The $\mathrm{NO}_{\mathrm{x}}$ is measured with the AC32M (Environment SA, France) analyser using gas-phase chemiluminescence technology. The $\mathrm{CO}$ level was measured using the model C012 (Environment SA, France) analyser based on the principle of infrared absorption and the gas filter correlation method. The VOC32M (Environment SA, France) analyser was used for the measurement of VOCs. It separates the targeted compounds based on gas chromatography and further analyses them using the photo-ionisation detection method. The analysers were operated as per the standard specifications for robust quality control and quality assurance. The USEPA's Standard Operating Procedures were adopted for instrument calibration. The number of standard calibration checks starting from zero to span calibrations is done routinely as per specified guidelines. Detailed information about the calibration procedure can be found elsewhere (http://www. law.cornell.edu/cfr/text/40/part-50). The continuous data obtained from the above measurement have been averaged for $24 \mathrm{~h}$ to get the daily average during the period 20th February to 14th April for both years 2019 and 2020, which includes period of lockdown as well as normal period prior to lockdown. The nationwide official lockdown in India started from 25th March 2020. However, Mumbai and Pune fall in the state of Maharashtra which was one of the first states to register the high number of cases in India. Due to this reason, all public places, schools, and industrial activities were voluntarily shut, and state authorities imposed restrictions well in advance. In view of this, we have considered the lockdown for these 2 cities from 17th March 2020 to April 14th 2020 in this work.

\section{Results and discussions}

\section{Change in $\mathrm{O}_{3}$ and its precursors during lockdown}

To understand the extent of reduction during the lockdown (17th March-14th April 2020), the averaged value is 


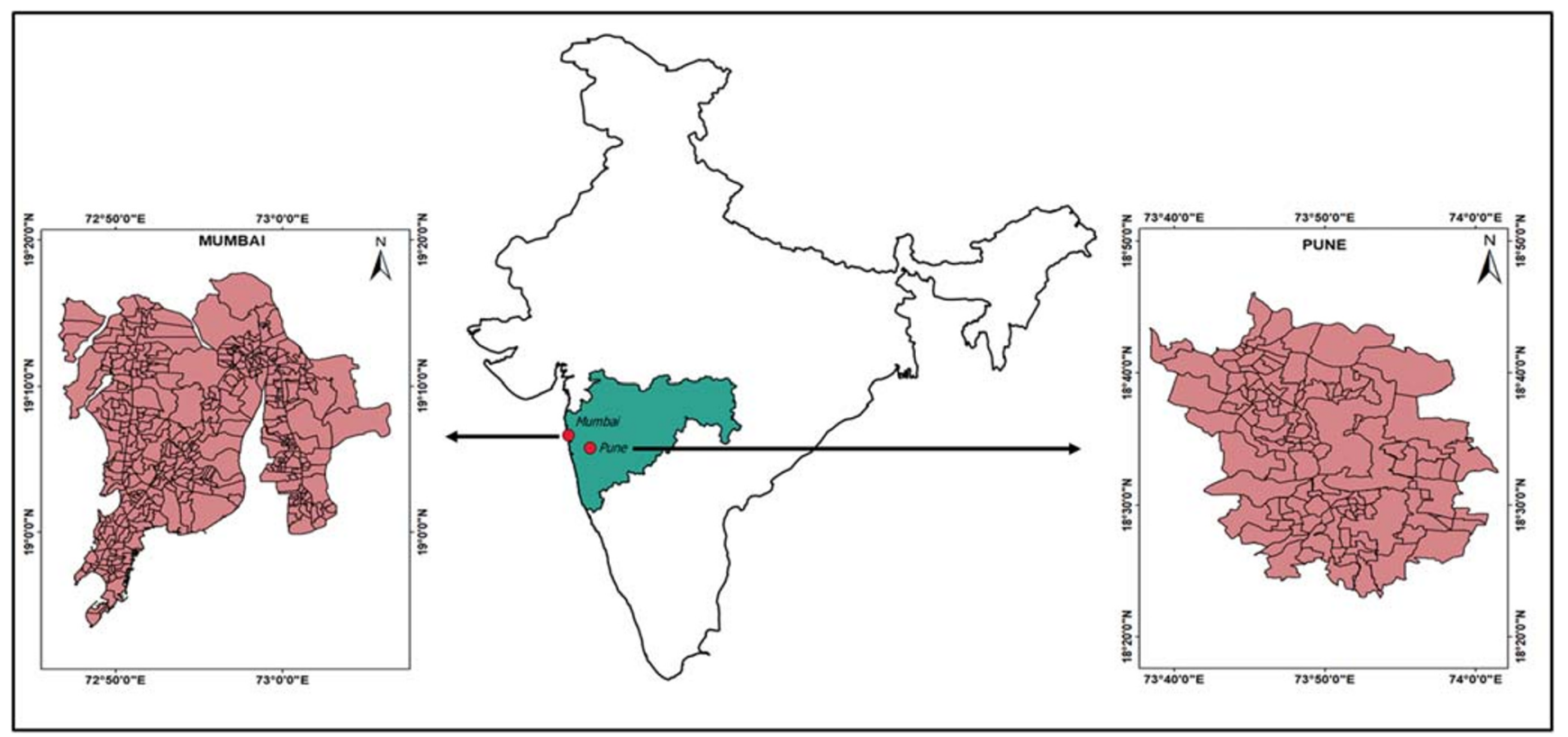

Fig. 1 Geographical locations of the study region Mumbai and Pune city domain

Fig. 2 Percentage change of $\mathrm{O}_{3}$, $\mathrm{CO}, \mathrm{NO}_{2}, \mathrm{NO}_{\mathrm{x}}$, and $\mathrm{VOC}$ during 2019 and 2020 during the

lockdown period in Mumbai and Pune
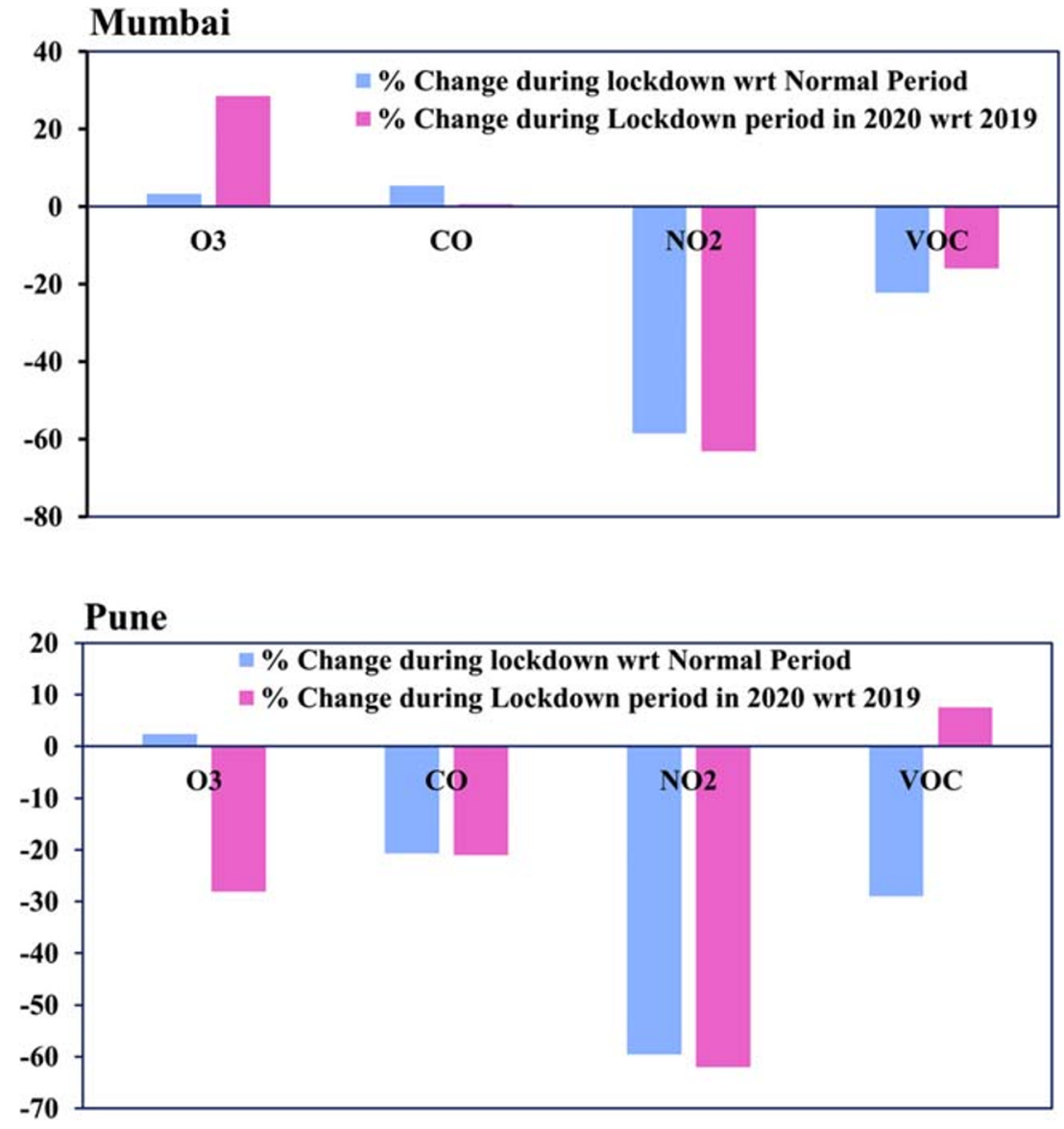

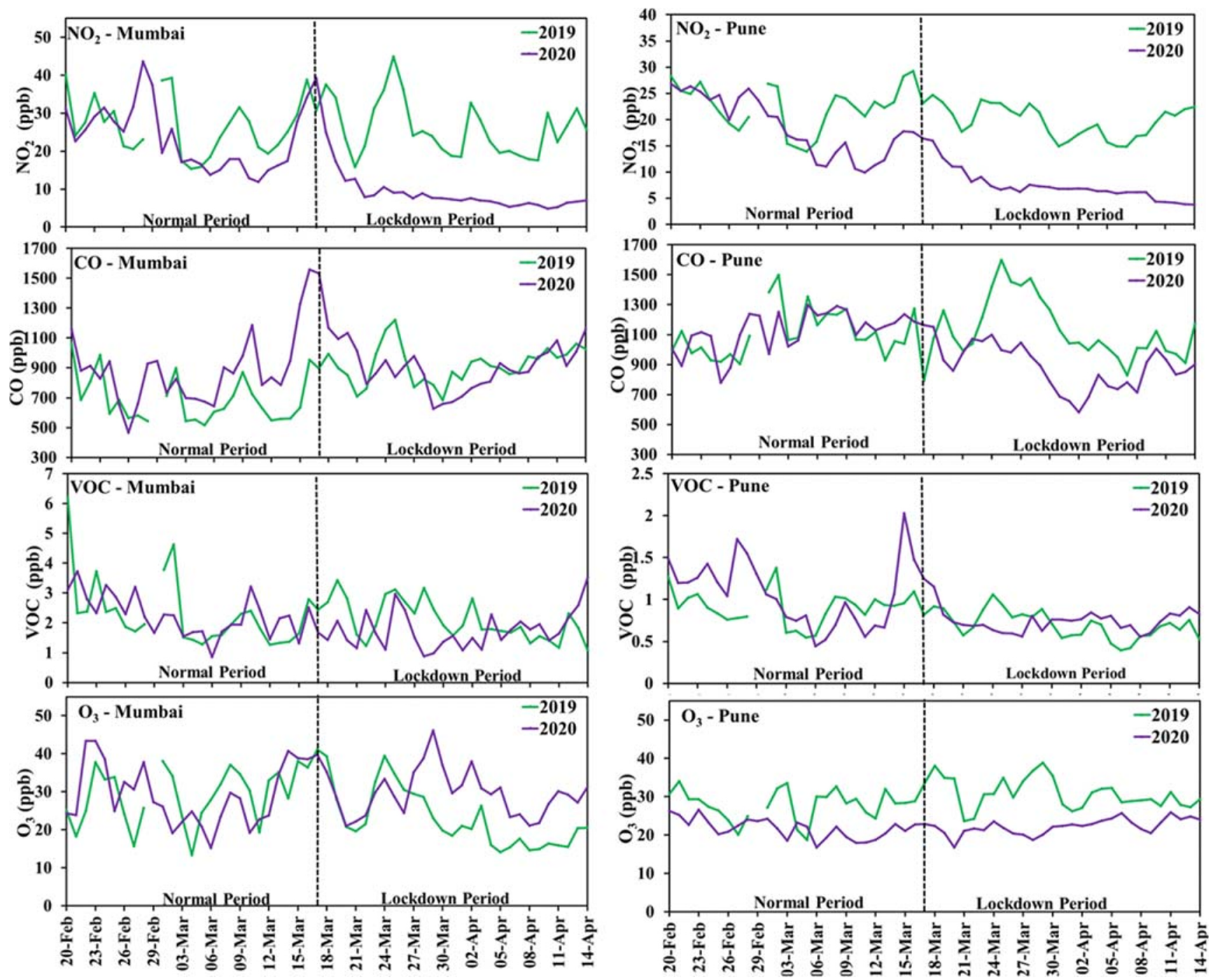

Fig. 3 Daily variability in $\mathrm{NO}_{2}, \mathrm{NO}_{x}, \mathrm{CO}, \mathrm{VOC}$, and $\mathrm{O}_{3}$ during 20th Feb to 14th April 2020 and 2019 in Mumbai and Pune

compared with the normal period prior to lockdown (20th Feb-16th March 2020) as well as with the averaged value of identical lockdown period in 2019 (17th March-14th April 2019). The percentage change thus obtained for $\mathrm{O}_{3}, \mathrm{NO}_{2}$, $\mathrm{CO}$, and VOCs is shown in Fig. 2. It is evident from this figure that the volume mixing ratio of $\mathrm{NO}_{2}$ shows a maximum reduction during the lockdown period when compared with 2019 in both the cities. The level of $\mathrm{NO}_{2}$ shows a reduction of $63 \%$ and $62 \%$ in Mumbai and Pune respectively during the lockdown period as compared to 2019. When we compare the lockdown period with the normal period in $2020, \mathrm{NO}_{2}$ shows a reduction of $60 \%$ in Pune $(60 \%)$ and $59 \%$ in Mumbai. The $\mathrm{CO}$ concentration in Mumbai does not show any appreciable change during the lockdown period, whereas a decrease of $21 \%$ is noticed in Pune. The VOC concentration shows a reduction during the lockdown period in Mumbai as well as in Pune when compared with the pre-lockdown period. However, ozone in both cities behaves very differently and exhibits an overall increase of 3\% and 2\% in Mumbai and
Pune respectively during the lockdown period. Recently, Sharma et al. (2020b) and Panda et al. (2020) have also shown an increasing trend during the lockdown in $\mathrm{O}_{3}$ concentrations. During the lockdown, almost all sources of emissions declined considerably except biofuel emissions which are mainly emitted from the residential sector by cooking activities. The contribution from biofuel sources in ozone precursors is relatively low as compared to Mumbai due to one of the largest slum clusters in India, where the majority of residence still use conventional sources for cooking like wood and coal (Beig et al., 2020). The above trend in Mumbai implies that the high emissions of biofuel sources are probably the major reason for the non-declining trend in $\mathrm{CO}$ and VOC where the share of biofuel is high.

The daily variability of $\mathrm{O}_{3}$ and its precursors, viz. $\mathrm{NO}_{2}$, $\mathrm{CO}$, and VOC, is shown in Fig. 3 for the period of 20th Feb to 14th April for 2019 and 2020. An increase in the concentrations of $\mathrm{NO}_{2}$, $\mathrm{VOC}$, and $\mathrm{CO}$ is observed from 15 th to 17 th March. This spike in the concentration could be due to people 
Fig. $4 \mathrm{NO} / \mathrm{NO}_{2}$ and $\mathrm{VOC} / \mathrm{NO}_{\mathrm{x}}$ ratio in $\mathbf{a}$ Mumbai and $\mathbf{b}$ Pune during 20th Feb to 14th April 2020
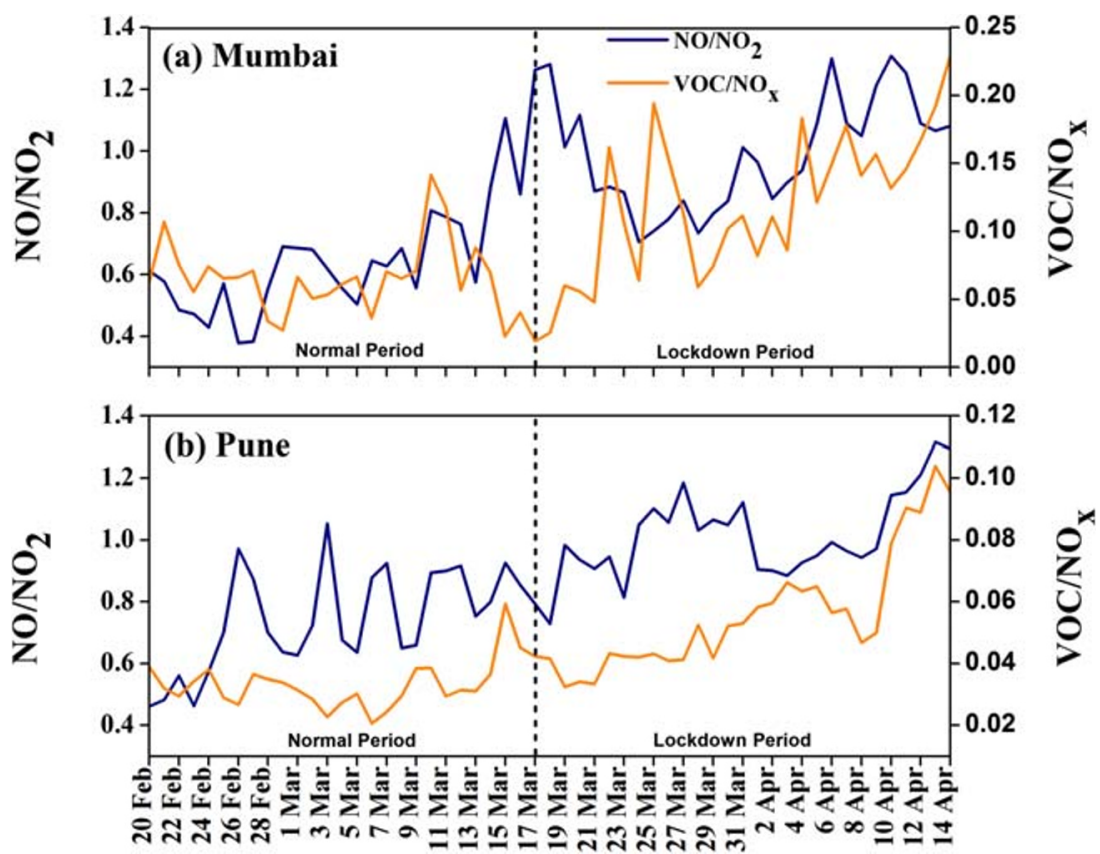

indulging in panic buying of daily essentials and outstation people travelling back to their hometowns due to the rumours of complete closure resulting in increased emissions for that short period. After 17th March, concentrations of $\mathrm{O}_{3}$ and its precursors $\left(\mathrm{NO}_{2}, \mathrm{VOCs}, \mathrm{CO}\right)$ started to decline. However, in Mumbai, $\mathrm{O}_{3}$ and VOC concentration showed an increasing trend from 22nd March, with two distinct peaks in ozone on 24th and 29th March. The level of VOC peaked on 22nd and 25th March. The level of $\mathrm{NO}_{2}$ started to decline sharply immediately after the lockdown before touching the saturation value of around 6-7 ppb, both in Mumbai and Pune. The saturation level in this work is defined as the minimum level reached after the lockdown under consistent fair weather conditions of major criteria pollutants. This level may be considered indicators of background level lowest concentration of $\mathrm{NO}_{2}$ observed for continuous 2-3 days after a sharp fall due to the drastic decrease in emissions. It is observed that the VOC concentration shows very low variability after a lockdown in Pune. However, in Mumbai, the concentration reduces as compared to the normal period. Immediately after the lockdown, the levels of $\mathrm{NO}_{2}$ declined sharply in both cities of Mumbai and Pune. The major contributor of $\mathrm{NO}_{2}$ is fossil fuel combustion related to transport sources. However, while levels of CO and VOC declined sharply in Pune, the levels of these species remain unaffected in Mumbai and do not show any declining trends.

To understand the variability of ozone during the lockdown period, it is important to discuss its fundamental chemistry with respect to its precursors. Surface ozone is formed through photochemical reactions involving $\mathrm{NO}_{\mathrm{x}}\left(\mathrm{NO}+\mathrm{NO}_{2}\right)$, VOCs, and $\mathrm{CO}$ in the presence of solar radiation. $\mathrm{O}_{3}$ formation is mainly initiated by the reaction of $\mathrm{VOC}$ or $\mathrm{CO}$ with the $\mathrm{OH}$ radical, followed by conversion of $\mathrm{NO}$ to $\mathrm{NO}_{2}$, and furthermore, $\mathrm{NO}_{2}$ is photolysed to form $\mathrm{O}_{3}$. The reactions followed in the formation of $\mathrm{O}_{3}$ are as given below (Sillman 2002)

$$
\begin{aligned}
& \mathrm{VOC}+\mathrm{OH} \rightarrow{ }^{\left\lceil\mathrm{O}_{2}\right\rceil} \mathrm{O}_{2}+\mathrm{H}_{2} \mathrm{O} \\
& \mathrm{CO}+\mathrm{OH} \rightarrow{ }^{\left\lceil\mathrm{O}_{2}\right\rceil} \mathrm{HO}_{2}+\mathrm{CO}_{2} \\
& \mathrm{HO}_{2}+\mathrm{NO} \rightarrow \mathrm{OH}+\mathrm{NO}_{2} \\
& \mathrm{NO}_{2}+\mathrm{h} v \rightarrow \mathrm{NO}+\mathrm{O} \\
& \mathrm{O}+\mathrm{O}_{2}+\mathrm{M} \rightarrow \mathrm{O}_{3}+\mathrm{M}
\end{aligned}
$$

The $\mathrm{O}_{3}$ formation rate is mainly determined by the reaction of VOC or $\mathrm{CO}$ with $\mathrm{OH}$. The production of $\mathrm{O}_{3}$ can be associated with $\mathrm{NO}_{\mathrm{x}}$-sensitive or VOC-sensitive regimes, although there are no straightforward explanations to distinguish the two regimes. However, as per the normal chemistry, if $\mathrm{NO}$ remains high as compared to $\mathrm{NO}_{2}$, the dissociation of $\mathrm{O}_{3}$ increases which implies that an increased $\mathrm{NO} / \mathrm{NO}_{2}$ ratio reduces the ozone concentration (Khalil et al., 2018). VOC/ $\mathrm{NO}_{\mathrm{x}}$ ratio is also a major factor in the $\mathrm{O}_{3}$ formation at a city level (Pusede and Cohen 2012; Y. Zou et al.2015).

As shown in Fig. 3, ozone concentration in Mumbai under normal condition (before lockdown) fluctuates between 20 and $45 \mathrm{ppb}$. The peak in ozone at $45 \mathrm{ppb}$ around $22 \mathrm{nd}$ February is associated with the lowest value of $\mathrm{NO} / \mathrm{NO}_{2}$ below 0.5 , where $\mathrm{NO}_{2}$ is found to be higher than NO. 

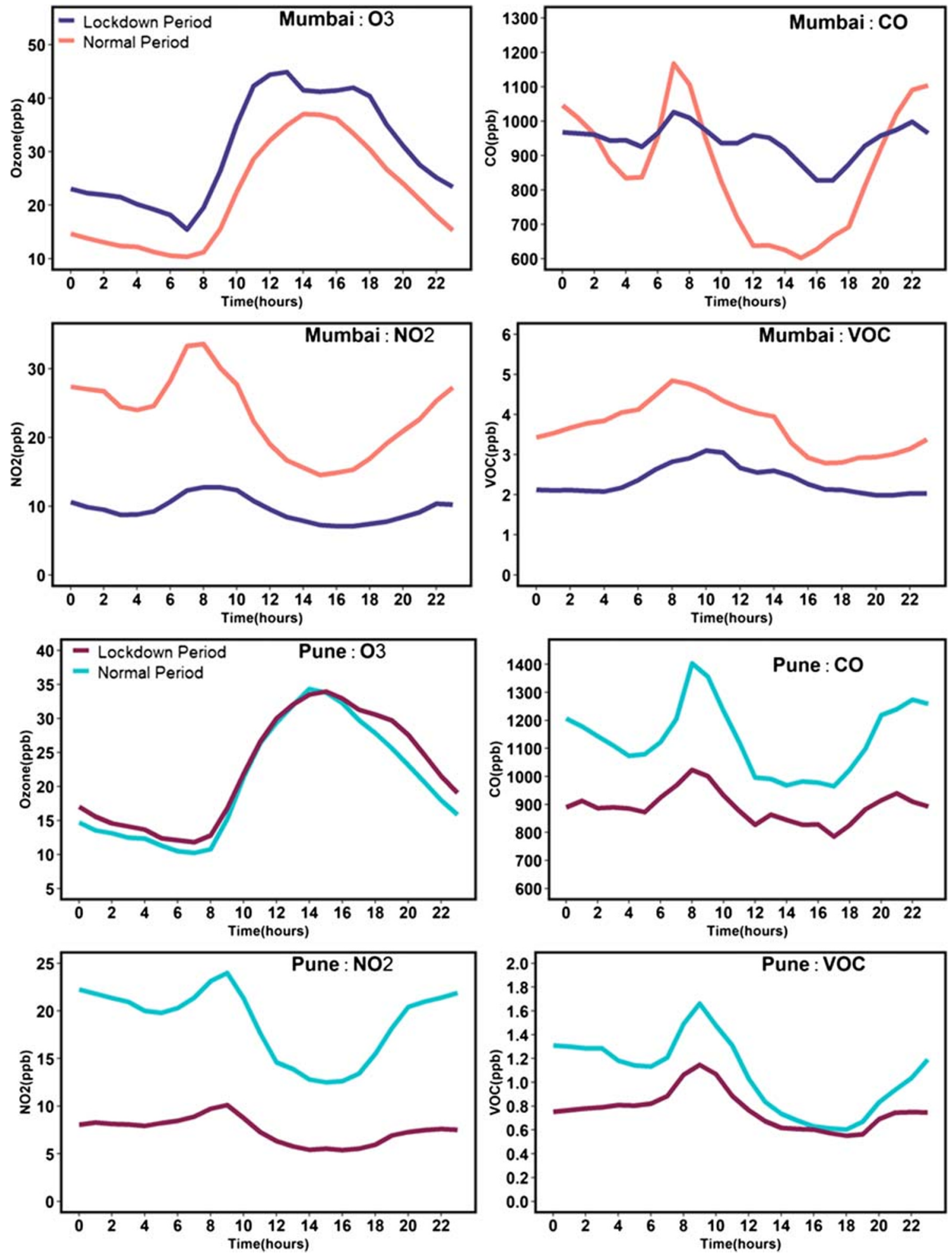

Fig. 5 Diurnal variability of $\mathrm{O}_{3}, \mathrm{CO}, \mathrm{NO}_{2}$, and $\mathrm{VOC}$ at Mumbai and Pune during the two periods: normal period and lockdown period

Thereafter, the ratio of $\mathrm{NO} / \mathrm{NO}_{2}$ increases marginally. The low value of ozone (20 ppb) on 10th March is associated with a peak value of 0.8 in the ratio of $\mathrm{VOC} / \mathrm{NO}_{\mathrm{x}}$ as well as $\mathrm{NO} / \mathrm{NO}_{2}$. After 10th March, the ratio of $\mathrm{NO} / \mathrm{NO}_{2}$ starts to increase, whereas the ratio of $\mathrm{VOC} / \mathrm{NO}_{\mathrm{x}}$ declines with interim fluctuations until the onset of lockdown on 17th March, and the ozone level initially increases and then became constant at $\sim 40 \mathrm{ppb}$. During this period, value of VOC declined. As evident from Fig. 3, immediately after the lockdown, the levels of $\mathrm{NO}_{2}$ and $\mathrm{CO}$ decreased sharply, and a fall 


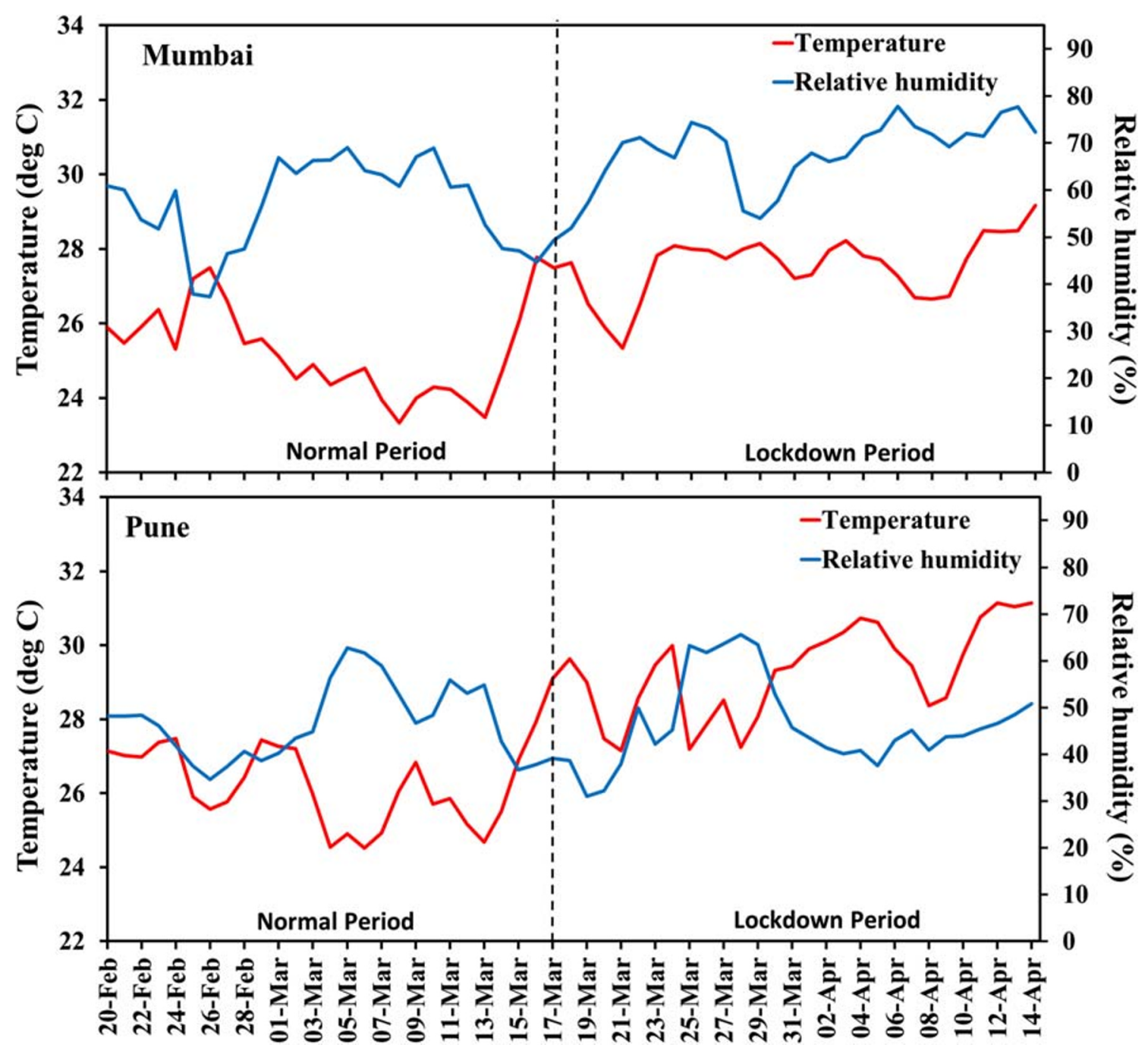

Fig. 6 Daily variability in temperature and relative humidity from 20th Feb to 14th April 2020 in Mumbai and Pune

in ozone amount from 38 (17th March) to $20 \mathrm{ppb}$ (20th March) is observed which is associated with a sharp increase in the $\mathrm{VOC} / \mathrm{NO}_{\mathrm{x}}$ ratio (Fig. 4a) from 0.1 to 1 , during which $\mathrm{NO}_{2}$ level touched a minimum level and remained almost constant at $\sim 8 \mathrm{ppb}$. Thereafter, ozone started to increase because the ratio of $\mathrm{VOC} / \mathrm{NO}_{\mathrm{x}}$ sharply declined, leading to the first peak in ozone on 24th March followed by a second peak on 29th March with a dip in between on 26th March, associated with a peak in $\mathrm{VOC} / \mathrm{NO}_{\mathrm{x}}$ ratio (Fig. 4b). The $\mathrm{NO} /$ $\mathrm{NO}_{2}$ ratio during the above period was declining until 29th March and then started to increase slightly. Hence, the decrease in $\mathrm{VOC} / \mathrm{NO}_{\mathrm{x}}$ ratio is associated with the increase in $\mathrm{O}_{3}$ concentration which was a result of lowering of VOC level. Hence, the variability of $\mathrm{O}_{3}$ on those days is controlled by $\mathrm{VOC} / \mathrm{NO}_{\mathrm{x}}$ levels, and a more complex $\mathrm{O}_{3}-\mathrm{NO}_{\mathrm{x}}-\mathrm{VOC}$ chemistry determines the $\mathrm{O}_{3}$ productivity. After 29 th March, although the ozone level in 2020 was still higher than 2019 , it started to decline because the ratio of $\mathrm{NO} / \mathrm{NO}_{2}$ started to increase along with the ratio of $\mathrm{VOC} / \mathrm{NO}_{\mathrm{x}}$ with some variabilities in between. Hence, the trend in ozone is inversely proportional to $\mathrm{VOC}$, while the level of $\mathrm{NO}_{\mathrm{x}}$ remains almost constant during most of the lockdown period after it gets saturated.

A study carried out in Chengdu, China, to explore the ozone pollution also concluded that ozone is highly sensitive to VOC in major Chengdu stations, and hence, its control is important for ozone control (Tan et al., 2018).

In the case of Pune, the $\mathrm{O}_{3}$ concentration does not show any appreciable trend after the lockdown and depicted almost a similar level as that of the normal period as clear from Fig. 3. Immediately after the lockdown, the ozone level indicated a weak declining trend with $\mathrm{O}_{3}$ concentration $20 \mathrm{ppb}$ until 21st March, during which levels of $\mathrm{NO}_{2}$ and VOC decline rapidly. This decline in ozone appears to be associated with an increase in the $\mathrm{NO} / \mathrm{NO}_{2}$ ratio $(0.8$ to 1) and a decline in the $\mathrm{VOC} / \mathrm{NO}_{\mathrm{x}}$ ratio (0.05 to 0.03 ) (Fig. $4 b)$. After 28th March, the levels of $\mathrm{NO}_{2}$ and VOC did not show any significant variability, and the concentration was 

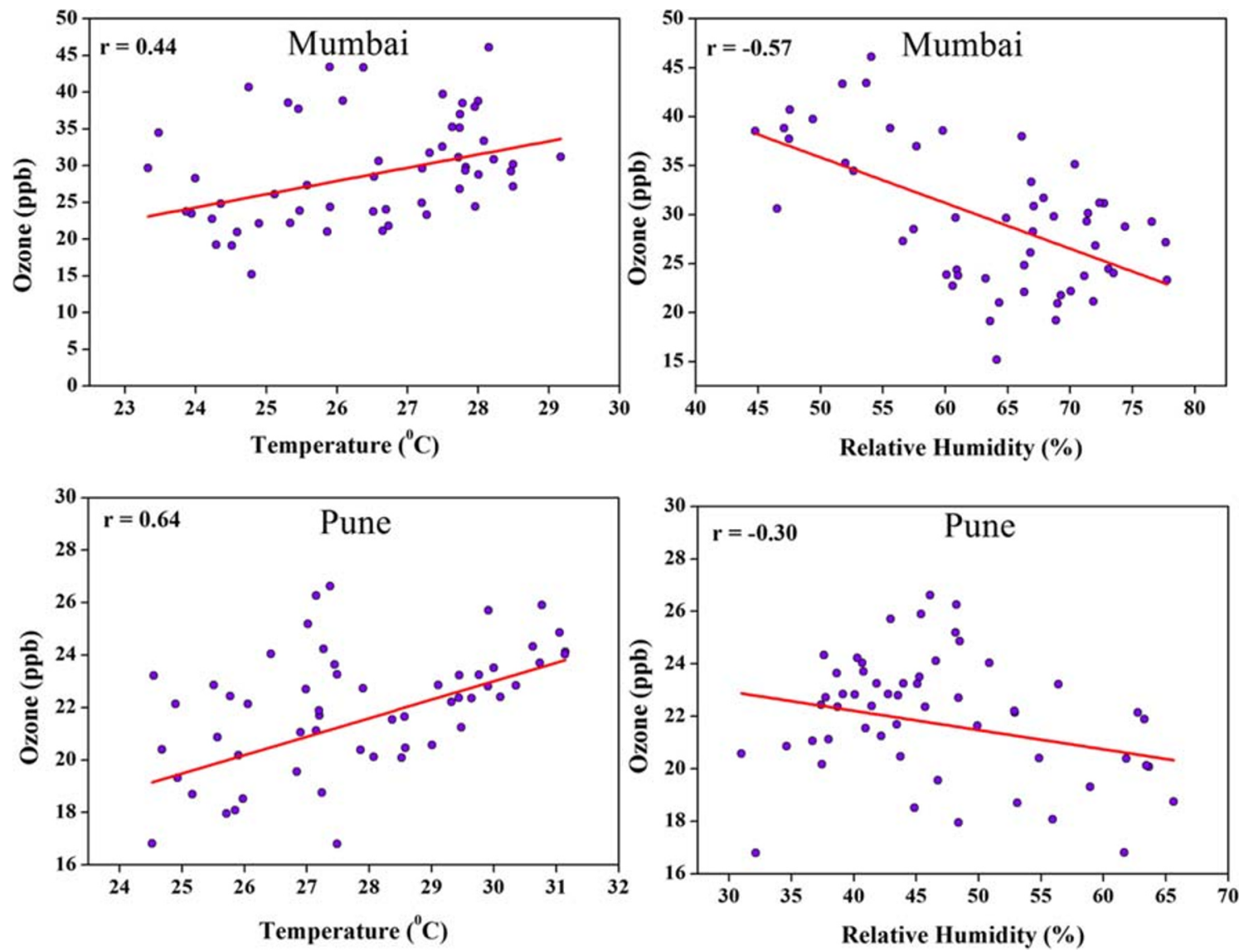

Fig. 7 Correlation between ozone and temperature, and relative humidity at Mumbai and Pune

low for these pollutants. The $\mathrm{NO} / \mathrm{NO}_{2}$ ratio also did not show any significant variability leading to almost negligible variability in $\mathrm{O}_{3}$ concentration. From 9th April onwards, the ratio of both $\mathrm{NO} / \mathrm{NO}_{2}$ and $\mathrm{VOC} / \mathrm{NO}_{\mathrm{x}}$ started to increase and hence cancelled out any impact in ozone which remained almost constant without any appreciable change till the end of the lockdown.

\section{Diurnal variation}

To understand the variability of the pollutants on an hourly basis, the diurnal variability of $\mathrm{O}_{3}, \mathrm{CO}, \mathrm{NO}_{2}$, and $\mathrm{VOC}$ is shown in Fig. 5 during the period from 20th February to 16th March (normal period) and 17th March to 14th April (lockdown period). The magnitude of diurnal variation is higher during the normal period as compared to the lockdown period for all 3 ozone precursors $\left(\mathrm{NO}_{2}, \mathrm{CO}\right.$, and VOC) in both cities with an exception of $\mathrm{CO}$ for Mumbai. This indicates a uniform decline in almost all hours, although in most cases, the peak associated with rush hours during normal time is either vanished or reduced significantly during the lockdown period. It is interesting to note here that the pattern of diurnal trend is maintained indicating that the relative decline in emissions of these pollutants is almost uniform. It is important here to state that some traffic-related activities related to essential services (food supply, health workers, emergency vehicles, and security personnel) were allowed during the lockdown, and hence a much smaller peak is a combination of the chemistry of precursor gases and some emissions related to traffic movements related to essential services. Recent studies (Singh et al., 2020 and Resmi et al., 2020) also report a similar diurnal trend in $\mathrm{NO}_{2}$.

The concentrations of $\mathrm{CO}$, VOCs, and $\mathrm{NO}_{2}$ in the normal period in Pune and Mumbai show a peak in the morning hours ( $\sim 800-900 \mathrm{~h})$; thereafter, it decreases during the day. In Mumbai, the same diurnal trend was not observed in $\mathrm{CO}$ levels during the lockdown period as that was there during the normal period. The lifetime of $\mathrm{CO}$ is relatively higher as compared to other precursors. Mumbai being a coastal city, there is large variability in the pollutant concentration due to the effect of the frequent reversal of sea to land and land to sea winds. The decrease in pollutant concentration is due to the cleaner winds from the sea, whereas the increase is due to the winds from the land which is reflected more prominently in $\mathrm{CO}$ due to its lifetime. The diurnal variability of $\mathrm{O}_{3}$ shows the general build-up with sunrise as photochemical production of ozone starts in the presence of sunlight. The level of ozone peaks in the afternoon time when the sun is overhead. The 
diurnal pattern in ozone in both cities is almost similar during normal and lockdown periods. The magnitude of ozone during lockdown is found to be higher as compared to normal time on almost all hours in Mumbai, whereas it is almost identical in Pune except for the night time, showing a marginal increase during the lockdown period.

\section{Association with meteorological parameters}

The photochemical formation of ground-level $\mathrm{O}_{3}$ is influenced by meteorological parameters along with its precursors. The variability in meteorological parameters such as temperature, relative humidity, and wind speed significantly affects the temporal variation in the levels of $\mathrm{O}_{3}$ (Reddy et al. 2012). Higher temperature increases the rate of photochemical reaction of $\mathrm{O}_{3}$ and the propagation of the radical chains and thus $\mathrm{O}_{3}$ formation (Jun Tu et al. 2007; Martins et al. 2012).

The average temperature during the study period varies in the range of $23-28^{\circ} \mathrm{C}$ in Mumbai and between 25 and $35^{\circ} \mathrm{C}$ in Pune (Fig. 6). The daily temperature is lower before the lockdown begins and started to rise after 15th March. The relative humidity in Mumbai is higher (40-80\%) as compared to Pune (30-60\%). In Pune, by the end of March, the temperature began increasing and thus the relative humidity dropped considerably. However, during the study period, the temperature was still lower than the peak summer temperature, and hence the impact of temperature is probably not found to be significant in both cities. Generally, during March to April months, north-westerly and westerly winds are dominant in Mumbai, while wind direction in Pune from March to April is found to be coming from west and southwest. Figure 7 shows the correlation between $\mathrm{O}_{3}$ concentration and temperature and relative humidity in both the cities of Mumbai and Pune. It can be observed that in both the cities, the correlation with $\mathrm{O}_{3}$ shows a positive correlation and the correlation coefficient is stronger in Pune $(r=0.64)$. Correlation of $\mathrm{O}_{3}$ with relative humidity shows a negative correlation in both the cities. The reduced relative humidity increases the surface $\mathrm{O}_{3}$ concentration. Thus, with an increase in temperature, it aids in the formation of higher $\mathrm{O}_{3}$ concentration, and relative humidity has an inverse relation to $\mathrm{O}_{3}$.

\section{Conclusions}

This paper discusses the variation in surface $\mathrm{O}_{3}$ and its precursors during the lockdown period and how it behaves in two cities which are in close proximity but having different geographical environments and thus having varying meteorology. It is observed that during the lockdown, while the ozone level increased, levels of its precursors declined considerably. The ozone variability during the lockdown in Mumbai is mainly controlled by the ratio of $\mathrm{VOC} / \mathrm{NO}_{\mathrm{x}}$. The coastal city Mumbai shows less reduction in $\mathrm{NO}_{2}$ and $\mathrm{VOC}$ as compared to Pune. It is observed that VOC played a major role in controlling the ozone behaviour during lockdown, underlining the fact that the air pollution mitigation strategies should be targeted more towards controlling the emission sources of VOCs.

Acknowledgements Indian Institute of Tropical Meteorology (IITM), Pune, supported this work. The authors are grateful to Director, IITM, and Secretary, Ministry of Earth Sciences, for their support.

Code availability Not applicable.

Authors' contributions Nikhil Korhale and Vrinda Anand carried out the analysis. Vrinda Anand and Nikhil Korhale wrote the manuscript with support from Gufran Beig. Gufran Beig supervised the study.

Data availability Data sharing is not applicable to this article.

\section{Compliance with ethical standards}

Conflict of interest The authors declare that they have no conflict of interest.

\section{References}

Anand V, Panicker AS, Beig G (2020) Gaseous pollutants over different sites in a metropolitan region (Pune) over India. SN Appl Sci 2:119. https://doi.org/10.1007/s42452-020-2472-2

Beig G, Chate M, Sahu SK, Parkhi NS, Srinivas R, Ali K, Ghude SD, Yadav S, Trimbake HK (2015), System of air quality forecasting and research (SAFAR-INDIA), 217, World Meteorological Organization, Global Atmosphere Watch, Geneva, Switzerland

Beig G, Bano S, Sahu SK, Anand V, Korhale N, Rathod A, Yadav R, Mangaraj P, Murthy BS, Singh S, Latha R, Shinde R (2020) COVID-19 and environmental-weather markers: unfolding baseline levels and veracity of linkages in tropical India. Environ Res 191: 110121. https://doi.org/10.1016/j.envres.2020.110121

Bao R, Zhang A (2020) Does lockdown reduce air pollution? Evidence from 44 cities in northern China. Sci Total Environ 731:139052. https://doi.org/10.1016/j.scitotenv.2020.139052

Fischer G, Frohne T, Gerharz L, Hildebrandt M, Klemm O, Mildenberger K, Nording C, Rehberger I, Schiffer M, Voulkoudis CS (2006) Change of the atmospheric NO/NO2-ratio in North RhineWestphalia (1984-2004) and possible causes. Umweltwissenschaften und Schadstoff-forsch 18:155-163. https://doi.org/10.1065/uwsf2006. 05.118

Hagenbjörk A, Malmqvist E, Mattisson K, Sommar NJ, Modig L (2017) The spatial variation of $\mathrm{O}_{3}, \mathrm{NO}, \mathrm{NO} 2$ and $\mathrm{NOx}$ and the relation between them in two Swedish cities. Environ Monit Assess 189: 161. https://doi.org/10.1007/s10661-017-5872-Z

Han S, Bian H, Feng Y, Liu A, Li X, Zeng F, Zhang X (2011) Analysis of the relationship between $\mathrm{O}_{3}, \mathrm{NO}$ and $\mathrm{NO} 2$ in Tianjin, China. Aerosol Air Qual Res 11:128-139. https://doi.org/10.4209/aaqr. 2010.07.0055

Kerimray A, Baimatova N, Ibragimova OP, Bukenov B, Kenessov B, Plotitsyn P, Karaca F (2020) Assessing air quality changes in large cities during COVID-19 lockdowns: the impacts of traffic-free urban conditions in Almaty, Kazakhstan. Sci Total Environ 730: 139179. https://doi.org/10.1016/j.scitotenv.2020.139179 
Khalil MAK, Butenhoff CL, Harrison RM (2018) Ozone balances in urban Saudi Arabia. npj Clim Atmos Sci 1:1-9. https://doi.org/10. 1038/s41612-018-0034-8

Khiem M, Ooka R, Huang H, Hayami H, Yoshikado H, Kawamoto Y (2010) Analysis of the relationship between changes in meteorological conditions and the variation in summer ozone levels over the central Kanto area. Adv Meteorol 2010:1-13. https://doi.org/10. $1155 / 2010 / 349248$

Lin Y, Jiang F, Zhao J, et al (2018) Impacts of $\mathrm{O}_{3}$ on premature mortality and crop yield loss across China. Atmos Environ 194:41-47. https:// doi.org/10.1016/j.atmosenv.2018.09.024. https://doi.org/10.1111/j. 1365-2486.2010.02217.x

Liu H, Liu S, Xue B, Lv Z, Meng Z, Yang X, Xue T, Yu Q, He K (2018) Ground-level ozone pollution and its health impacts in China. Atmos Environ 173:223-230. https://doi.org/10.1016/j.atmosenv. 2017.11.014

Lu X, Zhang L, Chen Y, Zhou M, Zheng B, Li K, Liu Y, Lin J, Fu TM, Zhang Q (2019) Exploring 2016-2017 surface ozone pollution over China: source contributions and meteorological influences. Atmos Chem Phys 19:8339-8361. https://doi.org/10.5194/acp-19-83392019

Martins DK, Stauffer RM, Thompson AM, Knepp TN, Pippin M (2012) Surface ozone at a coastal suburban site in 2009 and 2010: relationships to chemical and meteorological processes. J Geophys Res Atmos 117:1-16. https://doi.org/10.1029/2011JD016828

Melkonyan A, Kuttler W (2012) Long-term analysis of NO, NO 2 and O 3 concentrations in North Rhine-Westphalia, Germany. Atmos Environ 60:316-326. https://doi.org/10.1016/j.atmosenv.2012.06. 048

Mills G, Hayes F, Simpson D, Emberson L, Norris D, Harmens H, Buker P (2011) Evidence of widespread effects of ozone on crops and (semi-)natural vegetation in Europe (1990-2006) in relation to AOT40- and flux-based risk maps. Glob Chang Biol 17:592-613. https://doi.org/10.1111/j.1365-2486.2010.02217.x

Pancholi P, Kumar A, Bikundia DS, Chourasiya S (2018) An observation of seasonal and diurnal behavior of $\mathrm{O}_{3}-\mathrm{NOx}$ relationships and local/ regional oxidant $(\mathrm{OX}=\mathrm{O} 3+\mathrm{NO} 2)$ levels at a semi-arid urban site of Western India. Sustain Environ Res 28:79-89. https://doi.org/10. 1016/j.serj.2017.11.001

Panda S, Mallik C, Nath J, Das T, Ramasamy B (2020) A study on variation of atmospheric pollutants over Bhubaneswar during imposition of nationwide lockdown in India for the COVID-19 pandemic. Air Qual Atmos Heal. https://doi.org/10.1007/s11869-02000916-5

Pudasainee D, Sapkota B, Shrestha ML, Kaga A, Kondo A, Inoue Y (2006) Ground level ozone concentrations and its association with NOx and meteorological parameters in Kathmandu valley, Nepal, Atmospheric Environment. 40:8081-8087. https://doi.org/10.1016/ j.atmosenv.2006.07.011

Pusede SE, Cohen RC (2012) On the observed response of ozone to NOx and VOC reactivity reductions in San Joaquin Valley California 1995-present. Atmos Chem Phys 12:8323-8339. https://doi.org/ 10.5194/acp-12-8323-2012

Reddy BSK, Kumar KR, Balakrishnaiah G et al (2012) Analysis of diurnal and seasonal behavior of surface ozone and its precursors (NOx) at a semi-arid rural site in southern India. Aerosol Air Qual Res 12: 1081-1094. https://doi.org/10.4209/aaqr.2012.03.0055
Resmi CT, Nishanth T, Satheesh Kumar MK et al (2020) Long-term variations of air quality influenced by surface ozone in a coastal site in India: association with synoptic meteorological conditions with model simulations Atmosphere (Basel). 11:11. https://doi.org/10. 3390/atmos11020193

Sharma M, Jain S, Lamba BY (2020a) Epigrammatic study on the effect of lockdown amid Covid-19 pandemic on air quality of most polluted cities of Rajasthan (India). Air Qual Atmos Heal:1157-1165. https://doi.org/10.1007/s11869-020-00879-7

Sharma S, Zhang M, Anshika et al (2020b) Effect of restricted emissions during COVID-19 on air quality in India. Sci Total Environ 728: 138878

Shereen MA, Khan S, Kazmi A, Bashir N, Siddique R (2020) COVID-19 infection: origin, transmission, and characteristics of human coronaviruses. J Adv Res 24:91-98. https://doi.org/10.1016/j.jare. 2020.03.005

Sicard P, Anav A, De Marco A, Paoletti E (2017) Projected global ground-level ozone impacts on vegetation under different emission and climate scenarios. Atmos Chem Phys 17:12177-12196. https:// doi.org/10.5194/acp-17-12177-2017

Sillman S (2002) Chapter 12 The relation between ozone, NOx and hydrocarbons in urban and polluted rural environments. Dev Environ Sci 1:339-385. https://doi.org/10.1016/S1474-218177(02)80015-8

Singh RP, Chauhan A (2020) Impact of lockdown on air quality in India during COVID-19 pandemic. Air Qual Atmos Heal 13:921-928. https://doi.org/10.1007/s11869-020-00863-1

Singh V, Singh S, Biswal A, Kesarkar AP, Mor S, Ravindra K (2020) Diurnal and temporal changes in air pollution during COVID-19 strict lockdown over different regions of India. Environ Pollut 266:115368. https://doi.org/10.1016/j.envpol.2020.115368

Tan Z, Lu K, Jiang M, Su R, Dong H, Zeng L, Xie S, Tan Q, Zhang Y (2018) Exploring ozone pollution in Chengdu, southwestern China: a case study from radical chemistry to $\mathrm{O}_{3}$-VOC-NOx sensitivity. Sci Total Environ 636:775-786. https://doi.org/10.1016/j.scitotenv. 2018.04.286

Tobías A, Carnerero C, Reche C, Massagué J, Via M, Minguillón MC, Alastuey A, Querol X (2020) Changes in air quality during the lockdown in Barcelona (Spain) one month into the SARS-CoV-2 epidemic. Sci Total Environ 726:138540. https://doi.org/10.1016/j. scitotenv.2020.138540

Tu J, Xia Z, Wang H, Li W (2007) Temporal variations in surface ozone and its precursors and meteorological effects at an urban site in China. Atmos Res 85:310-337. https://doi.org/10.1016/j.atmosres. 2007.02.003

Wang D, Hu B, Hu C, Zhu F, Liu X, Zhang J, Wang B, Xiang H, Cheng Z, Xiong Y, Zhao Y, Li Y, Wang X, Peng Z (2020) Clinical characteristics of 138 hospitalized patients with 2019 novel coronavirusinfected pneumonia in Wuhan, China. JAMA - J Am Med Assoc 323:1061-1069. https://doi.org/10.1001/jama.2020.1585

WHO (2020) Coronavirus disease 2019. A A Pract 14:e01218. https:// doi.org/10.1213/xaa.0000000000001218

Zhang J, Wei Y, Fang Z (2019) Ozone pollution: a major health hazard worldwide. Front Immunol 10:1-10. https://doi.org/10.3389/ fimmu.2019.02518

Publisher's note Springer Nature remains neutral with regard to jurisdictional claims in published maps and institutional affiliations. 